\title{
Spatial-temporal change of the geomagnetic field: environmental aspect
}

\author{
M. I. Orlyuk, A.A. Romenets, 2020 \\ S.I. Subbotin Institute of Geophysics, National Academy of Sciences of Ukraine, \\ Kiev, Ukraine
}

Received 5 May 2020

\begin{abstract}
The geomagnetic field, along with other environmental factors, is a necessary component of life on the Earth. Currently, there are relevant ecological standards for the values of constant and variable fields. Taking them into account, it is possible to determine the conditions necessary for the normal functioning of biological objects in general and humans in particular. In a number of regulations, certain limit values for a constant magnetic field are introduced, as well as the maximum permissible time of a human being stay in such fields. In this regard, the article considers the spatial-temporal change in induction $B$ on the Earth's surface using the example of its main magnetic field according to the international model IGRF-13 for the time interval 1950-2020. In more detail for this time interval, the induction module $B$ and its perturbation were analyzed for geomagnetically different regions that are, namely, the territories of Ukraine, of Yamal (Russia) and around the ukrainian antarctic "Akademik Vernadsky» station. For the planet in whole, a significant decrease in the geomagnetic field is shown, against the background of which its sharp jumps are observed (in 1960-1965, 1980-1985 and in 2000-2005), and after 2005 to the present, a deceleration in the decrease of the geomagnetic field is observed. Against the background of a decrease in the geomagnetic field of the planet, areas with extreme changes both in the direction of increase (Ukraine, Yamal) and decrease ("AV» station) are distinguished. The spatial-temporal changes in the geomagnetic field detected on the Earth's surface determine the structure and dynamics of its magnetosphere, which by-turn affects the nature of the interaction with it of solar wind substance and of cosmic radiation, as well as the flow altitudes of magnetospheric and ionospheric currents. According to the distribution of the geomagnetic field anomalies on the surface of the planet, as well as to their changes over the studied time interval, regions with different (as compared with proposed ecological norms) values of the constant magnetic field and its disturbances are distinguished. In particular, for the epoch of 2020, for the territory in the vicinity of the "AV» station, the induction vector module $B$ is on average 15,000 nT less than its value for the territory of Ukraine and 25,000 nT — of Yamal. Significant changes in the geomagnetic field were determined: an increase of $1765 \mathrm{nT}$ for Ukraine, $1418 \mathrm{nT}$ for Yamal and a decrease of $-7081 \mathrm{nT}$ in the vicinity of "AV» station. At the same time, the perturbation of the geomagnetic field of the territory of Ukraine is within its ecological norm, deviates from it in the direction of increase on the Yamal Peninsula, and near the " $\mathrm{AV}$ » station it will soon go beyond its limits in the direction of decrease, while maintaining modern field changes.
\end{abstract}

Key words: geomagnetic field, spatial-temporal disturbance, IGRF, environmental norm, planet, Ukraine, Yamal, «Akademik Vernadsky» («AV») station.

Introduction. The geomagnetic field along with other environmental factors (gravitational field, air, temperature, pressure, humidity, etc.) is an extremely needed component of the existence of life on the Earth. The environmental aspect of the geomagnetic field boils down to two significant points, namely: a) it is a powerful power shell that protects the planet's surface from the ingress of solar plasma and charged particles of cosmic radiation in a wide frequency range; b) its presence, de facto, as a necessary parameter of the environment.

Currently, there are numerous data on the effect of constant and alternating magnetic fields in a wide range of frequencies on liv- 
ing organisms, in general, and on human life, in particular [Travkin, 1971; Pavlovich et al., 1991; Orlyuk, 2001; Physical ..., 2003; Serpov, 2007; Belokrinitsky, 2009; Serdyuk et al., 2010; Kulikov, Timofeeva, 2011; Medvedeva et al., 2011; Gorbunova, 2015 and many others]. In this regard, in the Department of Geomagnetism of the Institute of Geophysics of the National Academy of Sciences of Ukraine for almost 20 years a new scientific direction has been developing - geomagnetic ecology, which provides, first of all, a description and analysis of the spatial-temporal disturbance of the geomagnetic field, as one of the significant environmental factors [Orlyuk, 2001; Orlyuk, 2007, 2013; Orlyuk, Romenets, 2018], as well as a necessary "component» in interdisciplinary research [Orlyuk et al., 2007, 2012; Frolov et al., 2009; Kurnikov, Orlyuk, 2011, 2012; Melnyk et al., 2012, 2014; Orlyuk, Orliuk, 2012; Zasekin et al., 2013]. The geomagnetic field is considered as one of the determining factors in the functioning and development of the organic world.

The solution to these problems is seen in determining the values of the constant and variable components of the geomagnetic field at which a particular individual (population, ecosystem) can exist and develop, as well as the limiting values of these quantities at which their development and existence is impossible [Orlyuk, 2001]. In [Physical ..., 2003], the lower limit of the sanitary norm for the magnitude of the constant magnetic field is half the background values of the field in the territory of residence. Considering the fact that the geomagnetic field on the Earth's surface varies in a very wide range, the value of the "ecological» norm of a constant field in the range of $35-55 \mu \mathrm{T}$ is proposed in [Orlyuk, Romenets, 2005]. In connection with the analysis of the working and living conditions of people to date, with respect to a constant magnetic field, not only its limiting values have been introduced, but also the maximum time possible to stay in such fields [Standart ..., 2008; Snandard ..., 2015]. Norms have also been developed for alternating highfrequency magnetic and electromagnetic fields [ICNIRP Guidelines, 1998]. Note that in large megacities, the Earth's natural magnetic field is substantially supplemented by the technogenic component from various electric and ferromagnetic sources [Havas et al., 2004; Orlyuk, Romenets, 2003, 2004; Henzl et al., 2006; Lowes, 2009; Tyagunov, 2011; Rezinkina et al., 2009; Romenets, Orliuk, 2013; Orlyuk et al., 2016]. Therefore, in each specific case (place and time) it is necessary to characterize the magnetic field numerically and draw conclusions about its "environmental friendliness" on the basis of a comprehensive analysis of its natural and man-made components.

In this regard, the article first of all considers the spatial-temporal change in induction $B$ on the Earth's surface using the example of its main magnetic field ( $B_{\text {IGRF }}$ ) as a whole, which reflects the vast majority of the total changes for the time interval 1950-2020. In more detail for this time interval, the induction module and its perturbation are analyzed for regions that are geomagnetic different, namely the territory of Ukraine, Yamal (Russia) and around the ukrainian antarctic «Akademik Vernadsky» («AV») station.

The spatial-temporal perturbation of the geomagnetic field means its difference at some point from a certain norm (for the spatial case) or its regular change (for temporary changes). As already noted, currently there are relevant environmental standards for the values of constant and variable fields, taking into account which, determine the conditions necessary for the normal functioning of biological objects in general and humans in particular [Orlyuk et al., 2005; Serpov, 2007; Standart ..., 2008; Rozov et al., 2013]. From this point of view, it is interesting to consider the parameters of the geomagnetic field of the Earth as a whole, as well as various regions of its northern and southern hemispheres.

Purpose of work. To perform an analysis of the spatial-temporal change in the Earth's magnetic field as a whole, as well as the geomagnetic regions of Yamal, Ukraine and the "AV» station in the time interval 1950-2020 to evaluate them as an environmental factor.

Research Methodology. An estimate of the spatial-temporal perturbation of the geomagnetic field requires the presence of dif- 
ferent-scale maps: anomalies in the magnetic field induction module $\Delta B_{\mathrm{a}}$, its normal component $B_{\text {norm }}$ (as the Earth's normal magnetic field, we used the analytical model $B_{\text {IGRF }}$ (International Geomagnetic Referenc Field)) and finally the induction module $B$.

In the work, standard techniques were used in the individual stages of assessing the spatial-temporal disturbance of the geomagnetic field, namely: constructing maps of the anomalous magnetic field; calculation of the normal geomagnetic field $B_{\text {IGRF }}$; calculation of the induction module of the geomagnetic field $B$; estimates of the spatial-temporal disturbance of the geomagnetic field for the planet as a whole and its individual regions.

The most laborious moment is the development of maps of the anomalous component of the magnetic field $\Delta B_{\mathrm{a}}$. Corresponding maps are developed according to groundbased, aeromagnetic and satellite imagery. The scale of the maps is determined by the density of the observation network. To create a conditional map, it is necessary to take into account variations in the Earth's external magnetic field, which in this case are interferences and to bring the results to the middle of the year. Therefore, usually the work procedure provides for:

a) synchronous observations of module $B$ at the measurement points and at the magnetic observatory. This technique makes it possible to exclude the variational component of the magnetic field $\delta B$ and obtain absolute values of the module $B$ for the observation points at the time of the $B_{\mathrm{abs}}=$ $=B-\delta B$. The variational component $\delta B$ is defined as the difference between the measured values of the induction modulus $B$ and its average annual value;

b) abnormal values of the module are determined by the expression $\Delta B_{\mathrm{a}}=B_{\mathrm{abs}}-B_{\text {IGRF }}$. Here the $B_{\text {IGRF }}$ is the value of the normal component of the international geomagnetic field of relativity at the point of observation.

To solve the set tasks, digital arrays were first generated and $B_{\text {IGRF }}$ digital maps were built for the entire globe with a step of 5 years for the time interval 1950 - 2020. Calcu- lation of $B_{\text {IGRF }}$ was performed on-line with a step of $1^{\circ} \times 1^{\circ}$ in longitude and latitude using NASA software DGRF-IGRF Geomagnetic Field Model 1590 - 2024, international model IGRF-13 (https://ccmc.gsfc.nasa.gov/modelweb/models/igrf_vitmo.php). The beginning of the calculations was taken in 1950, then the field change over 5 years was determined as the difference between its values in 1955 and $1950\left(d B_{\text {IGRF }}(1955-1950) / d t=B_{\text {IGRF }}(1955)-\right.$ - $B_{\text {IGRF }}(1950)$ ), for 10 years - as the difference between 1960 and $1950\left(d B_{\text {IGRF }}(1960\right.$ - 1950)/ $d t=B_{\text {IGRF }}(1960)-B_{\text {IGRF }}(1950)$ ), and so on until 2020. This approach allows us to analyze both the field gradient for every 5 years and its total values for longer intervals. Temporary changes in the $B_{\text {IGRF }}$ field for individual points were calculated in increments of 1 year.

So, having arrays of fields $\Delta B_{\mathrm{a}}$ and $B_{\text {IGRF' }}$ for any time (epoch) for an arbitrary point, it is possible to determine the absolute value of the induction of the geomagnetic field: $B_{\mathrm{abs} i}=$ $=\Delta B_{\mathrm{a}_{i}}+B_{\mathrm{IGRF} i}$ (here $i$ is the corresponding era).

Due to the fact that the values of the anomalous magnetic field $\Delta B_{\mathrm{a}}$ are determined by the sources in the Earth's lithosphere and are practically unchanged (constant, with the exception of the magnetizing effect, which in most cases is insignificant with respect to the magnitude of the anomalies [Orlyuk, Romenets, 2005; Starostenko et al., 2013]), the absolute values of the geomagnetic field will depend only on secular changes in the main field, which are displayed in the values of the normal field $B_{\text {IGRF. }}$. We note in this case that the accuracy of constructing maps of the induction module in different regions is predetermined by the accuracy (error) of the models of the Earth's main magnetic field. Currently, this is becoming especially important, since $B_{\text {IGRF }}$ maps are compiled once every 5 years, and the geomagnetic field changes quite quickly. Accordingly, to calculate the absolute values of the geomagnetic field induction for a certain epoch, it is necessary to evaluate the sum of the anomalous and normal geomagnetic fields. Suppose, for the era of 1950, the absolute values of the induction of the geomagnetic field are calculated by the formula $B_{\text {abs, } 1950}=\Delta B_{\mathrm{a}}+B_{\mathrm{IGRF}, 1950}$ etc. 
For further calculations, we used digital data on the anomalous magnetic field obtained on the basis of published and available digital maps for the territory of Yamal [Makarova, 1977; Purucker, 2007] and Ukraine [Orlyuk, Romenets, 2005; Orlyuk et al., 2017, 2018a]. A digital map was used for the territory in the vicinity of the " $\mathrm{AV}$ » station, developed by the authors based on the results of expeditionary work in 2005-2008 [Orlyuk et al., 2008; Orlyuk, Romenets, 2008, 2009].

The spatial-temporal perturbation of the Earth's magnetic field was estimated by the criterion proposed by us [Orlyuk, Romenets, 2005] in accordance with the expression $\Delta D=$ $=\left(B-B_{\text {norm }}\right) / 2 B_{\text {norm }}$ (here $\Delta D$ is the spatial perturbation of the Earth's geomagnetic field, $B$ is the absolute value of the total vector of the geomagnetic field, $B_{\text {norm }}$ is the normal geomagnetic field of $B_{\text {IGRF. According to the }}$ expression $\Delta D$ is the dimensionless, insignificant in intensity, and therefore the unit of perturbation of the Earth's magnetic field - Distortion - is introduced $\left(1 D=10^{5}\right.$ c.u. $)$.

The environmental aspect is based on the «environmental norm» of the geomagnetic field, which for a constant field we take equal to $45,000 \mathrm{nT}$ and an on the estimate versus this norm of the magnetic field perturbation $\Delta D_{\text {ecol }}=\left(B-B_{\text {ecol }}\right) / 2 B_{\text {ecol }}$, where $B_{\text {ecol }}=45000 \mathrm{nT}$. Geomagnetically favorable regions are those in which the spatial-temporal perturbation of the field is within $\pm 10000 \mathrm{D}$. This issue has been considered in more detail in a number of authors' works [Orlyuk, Romenets, 2005, 2018b].

Also, for analysis were used a number of surface temperature anomalies for the period 1950-2019 (anomalies are calculated from the meteorological norm of 1961-1990) and temperature series for weather stations "AV», Salekhard, and Kiev for the same period.

Geomagnetic field and its spatial-temporal disturbance. The spatial-temporal structure of the geomagnetic field of the planet as a whole, as well as of its separate regions, has been the subject of a large number of works that used the results of observations in observatories, of ground-based, aerial and satellite surveys [Thébault et al., 2010, 2015;
Mandea, Korte, 2011; Purucker, Clark, 2011; Maksymchuk et al., 2010, 2012, 2013, 2015; Orlyuk et al., 2012, 2017; Duma et al., 2013; Tregubenko et al., 2013; Dyment et al., 2016; Finlay et al., 2016; Olsen et al., 2017; Maksymchuk, Orlyuk, 2018; Witze, 2019]. The cited works reflect the state and change of the geomagnetic field for different regions and time intervals, indicating its significant spatial heterogeneity and substantial dynamics of its various components. In this article, the change in the geomagnetic field is considered and analyzed, namely, using calculated data arrays, as well as $B_{\text {IGRF }}$ maps were constructed for the epochs of 1950-2020. (Fig. 1, $a, b)$. This made it possible to trace the field dynamics over 70 years (Fig. 1, c) and draw conclusions about the change in the magnitude of the normal component as a whole.

In accordance with calculations on the surface of the planet, the maximum values of the main magnetic field of the Earth $B_{\text {IGRF }}$ for 1950 and 2020 are characteristic for the negative magnetic pole $\left(B_{\mathrm{IGRF}}, 1950=69000 \mathrm{nT}\right.$, $B_{\text {IGRF, 2020 }}=66900 \mathrm{nT}$ ) (located near the Earth's geographical North Pole) and positive (located near the Antarctic coast opposite Australia), and the minimum ones for the near-equatorial regions of the South Atlantic (the socalled South Atlantic Anomaly) ( $B_{\text {IGRF, } 1950}=$ $=24500 \mathrm{nT}, B_{\mathrm{IGRF}}, 2020=22300 \mathrm{nT}$ ) (see Fig. $1, a, b)$.

For the period from 1950 to 2020 the average $B_{\text {IGRF }}$ value on the planet's surface decreased by $1797 \mathrm{nT}$ (from 47603 to 45806 nT) (Fig. 2). Naturally, a decrease in the induction modulus of the geomagnetic field on the planet's surface reflects a corresponding change in its dipole moment $\mathrm{M}$, from $31,200 \mathrm{Am}^{2}$ in 1950 to $29,800 \mathrm{Am}^{2}$ in 2020 (about $4.5 \%$ ).

Against the background of a general decrease in the magnetic field of the planet, areas with extreme values of its change are standing out. The maximum field decreases from 1950 to 2020 (from -5500 to $-7400 \mathrm{nT}$, from -80 to $-100 \mathrm{nT} /$ year) are located near the Atlantic coast of Central America $\left(18^{\circ} \mathrm{N}\right.$; $-65^{\circ} \mathrm{W}$, as well as in the region the Drake Strait $\left(-65^{\circ} \mathrm{S} ; 85^{\circ} \mathrm{W}\right)$ and between Africa 
and Antarctica $\left(-50{ }^{\circ} \mathrm{S} ; 10^{\circ} \mathrm{E}\right)$. Field increase maxima (2100 - 3500 nT, 40-60 nT/year) are typical for Europe $\left(60^{\circ} \mathrm{N} ; 30^{\circ} \mathrm{E}\right)$ and the Indian Ocean $\left(30^{\circ} \mathrm{S} ; 70^{\circ} \mathrm{E}\right.$ ) (see Fig. 1, c). Note that the European field maximum for the studied time interval practically corresponds to the East European Craton, which is of undoubted interest in relation to the study of the nature of such a correlation. For a more visual notion of the scale of secular changes in the geomagnetic field of different regions of the planet, Fig. 2 presents graphs of its changes (Fig. 2,a) and the rate of change for the planet as a whole (curve 1), "AV» station (curve 2), Salekhard (curve 3) and Kyiv (curve 4).

As can be seen from Fig. 2, for the planet as a whole, as noted earlier, a decrease in the field by almost $1800 \mathrm{nT}$ is observed (curve 1 in Fig. 2,a). The time flow of these changes seems interesting, namely: against the background of a general decrease in the field (at a rate of about $-25 \mathrm{nT} /$ year), its sharp jumps are observed (up to - $45 \mathrm{nT}$ /year in 1960-1965; -58 nT/year in 1980-1985; -32 nT/year in 2000-2005) after which over the next 15 years there was a less intensive decrease in its changes (to -18 nT/year in 1975; -12 nT/year in $1995 ;-2$ nT/year in 2015) (curve 1 in Fig. $2, b)$. From all this it can be concluded that, starting from 1985 to the present, there is a slowdown in the geomagnetic field decrease. Since the beginning of the $70 \mathrm{~s}$, a similar pattern of changes in the geomagnetic field has been observed for the "AV» station (which is located in almost one of the foci of the maximum decrease in the geomagnetic field), for which the field is also decreasing, however, in contrast to the planet as a whole, after 2000 years, it decreases more intensively from - 86 nT/year (in the interval 2000-2010) to $-96 \mathrm{nT} /$ year after 2010 . The opposite picture of field dynamics is observed for the territories of Ukraine and Yamal. For Salekhard, maximum field increases are confined to 1955 (61 nT/year), 1975 (29 nT/year) and 2000 (43 $\mathrm{nT} /$ year). Between these years, changes in the geomagnetic field slow down to $9 \mathrm{nT} /$ year in 1970, and even to negative values $(-10 \mathrm{nT} /$ year $)$ in 1985. After 2000, a more or less regular decrease in the growth of the geomagnetic field to $21 \mathrm{nT}$ /year in 2017 was established. It should be noted here that the growth of the geomagnetic field rate slows down. The logical expansion of the geomagnetic field is characteristic for the territory of Ukraine. In this case, the field growth is less differentiated with relative maximums in 1975 (33 nT/year) and 2000 (35 nT/year) and a minimum in 1985 (13 nT/year). On the territory of Ukraine from 1985 to the present, there has been an increase in the growth of the geomagnetic field (44 nT/year) in 2015. Therefore, it can be noted that the increase in the geomagnetic field of Ukraine differs from the increase fixed for the planet as a whole and Yamal, for which its relative decrease is noted. According to the Geomagnetic Observatory «Kiev », a very intensive increase in the growth of the geomagnetic field $d B_{\text {obs }} / d t$ has been observed over recent years (Fig. 3). In particular, from 2005 to 2009, a more or less monotonous decrease in the growth of both the $d B_{\text {obs }} / d t$ induction module (from 30 $\mathrm{nT} /$ year to $26 \mathrm{nT} /$ year) and its normal component $d B_{\mathrm{IGRF}} / d t$ (from $32 \mathrm{nT} /$ year to $29 \mathrm{nT}$ / year). After 2009, the increase in induction module $B$ increases to $42 \mathrm{nT} /$ year in 2015 and to $62 \mathrm{nT}$ /year in 2018 ( see Fig. 3, b, curve 1). A smaller increase is characteristic for $B_{\mathrm{IGRF}}$, which, with small deviation, reaches $42 \mathrm{nT} /$ year in 2015 and remains the same for the next 4 years (see Fig. 3, b, curve 2). For the considered time interval, one more regularity can be noted, namely, from 2005 to 2010, the increase in the $d B_{\mathrm{IGRF}} / d t$ field was larger than the increase in the $d B_{\text {obs }} / d t$ values observed in the observatory, from 2011 to 2015 (except for 2014) it was almost the same, and from 2016 it was sharp increase in the observed values (up to $17 \mathrm{nT}$ /year in 2018) relative to the increase in the normal field. Apparently, this may indicate the problem of constructing models of the Earth's normal magnetic field $B_{\text {IGRF, }}$ since it is doubtful that the anomalous component of the induction module $\Delta B$ can undergo such rapid temporary changes.

Based on the foregoing, when studying the spatial-temporal structure of the induction module $B$ for some territories, information on regional and even global features of the $B_{\mathrm{IGRF}}$ 

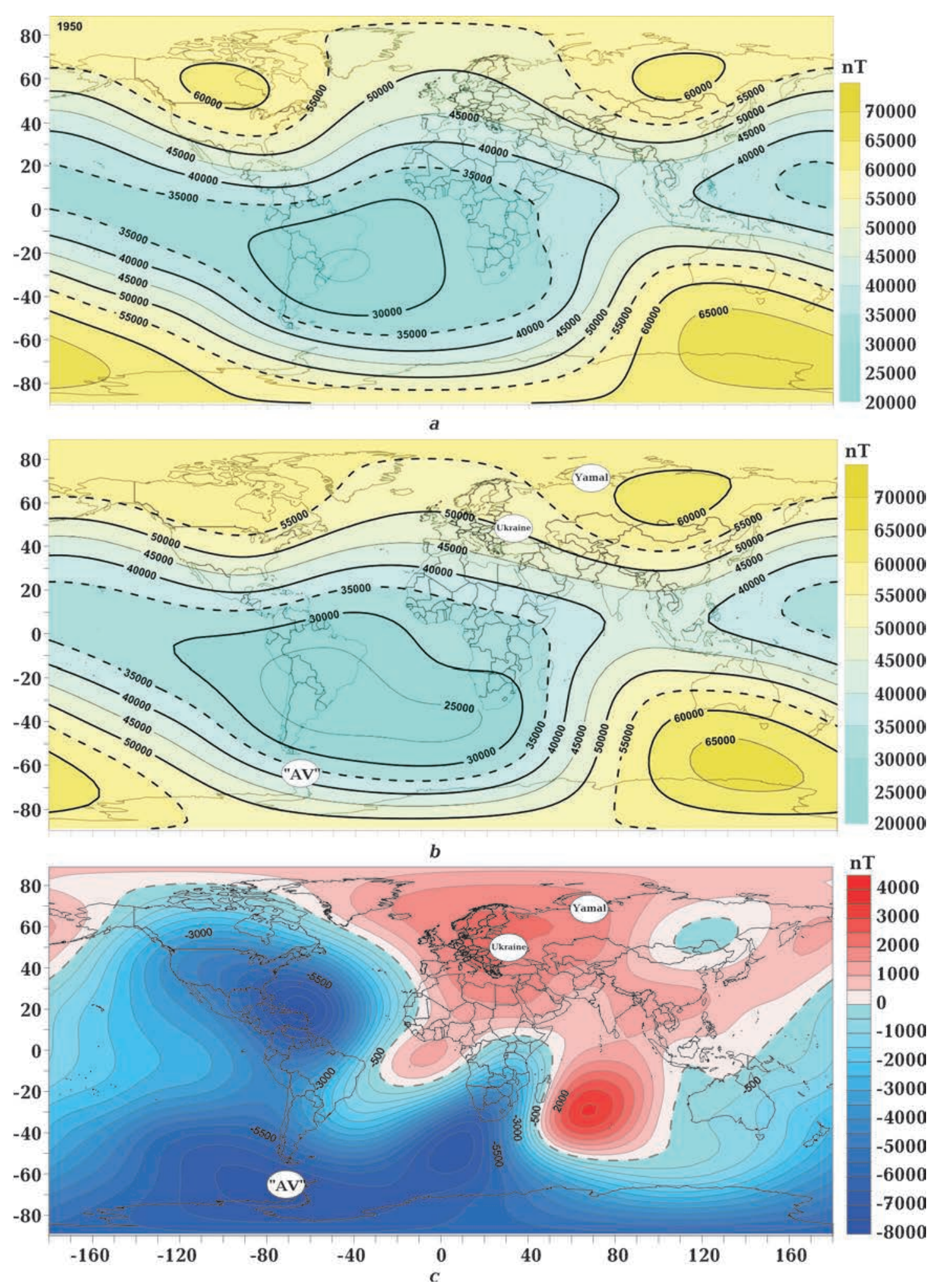

Fig. 1. The main magnetic field of the Earth $B_{\mathrm{IGRF}}$ for the epoch $1950(a)$, the epoch $2020(b)$, its temporary changes for the interval 1950-2020 (c) and the layout of studied regions.

parameter is extremely important. In this regard, the structure of the secular variation of the magnetic field $B_{\mathrm{IGRF}}$ on the Earth's surface was analyzed using the international model IGRF-13. As can be seen on the given map of the secular variation of the $B_{\text {IGRF }}$ (see Fig. $1, c$ ), 


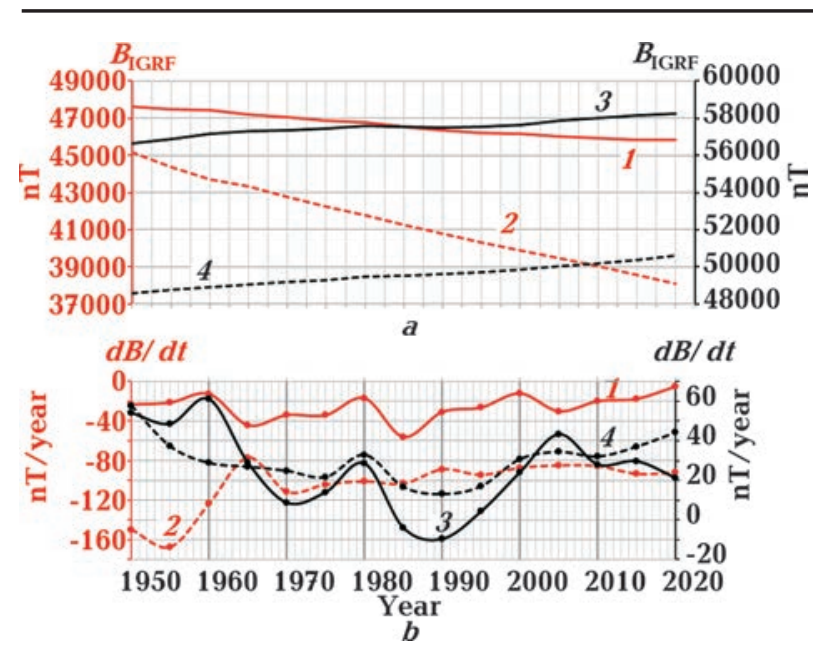

Fig. 2. The dynamics of the main magnetic field induction of the Earth $B_{\text {IGRF }}(a)$ over 70 years (1), at the "AV" station $\left(65^{\circ} 15^{\prime} \mathrm{S}, 64^{\circ} 15^{\prime} \mathrm{W}\right)(2)$, in the city of Salekhard (Yamal) $\left(66^{\circ} 32^{\prime}\right.$ N, 66 $38^{\prime}$ E) (3) and Kyiv (Ukraine) $\left(50^{\circ} 27^{\prime} \mathrm{N}, 30^{\circ} 3^{\prime} \mathrm{E}\right)(4)$ and its temporary changes $(b)$ respectively.

intense anomalies (foci) are observed that form the character of the SV field in Ukraine, Yamal, and in the vicinity of the "AV» station.

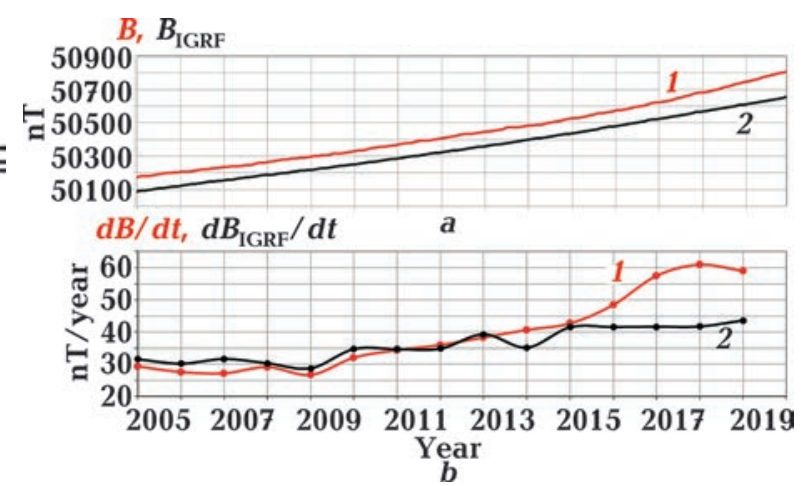

Fig. 3. The dynamics of the induction module of the geomagnetic field $B_{\text {obs }}$ (curve 1) and its normal component $B_{\text {IGRF }}$ (curve 2) (a), as well as their temporal changes for the Kyiv magnetic observatory (b).

\section{Induction module $B$ and its spatial-tem-} poral disturbance for the territories of Ukraine, Yamal and the «AV» station. The territories of Ukraine, Yamal, and «AV» are in quite different «geomagnetic» conditions [Orlyuk, Romenets, 2017, 2018a,b]. In particular, Ukraine (Fig. 4, a) is located in middle geomagnetic latitudes with a rather differentiat-

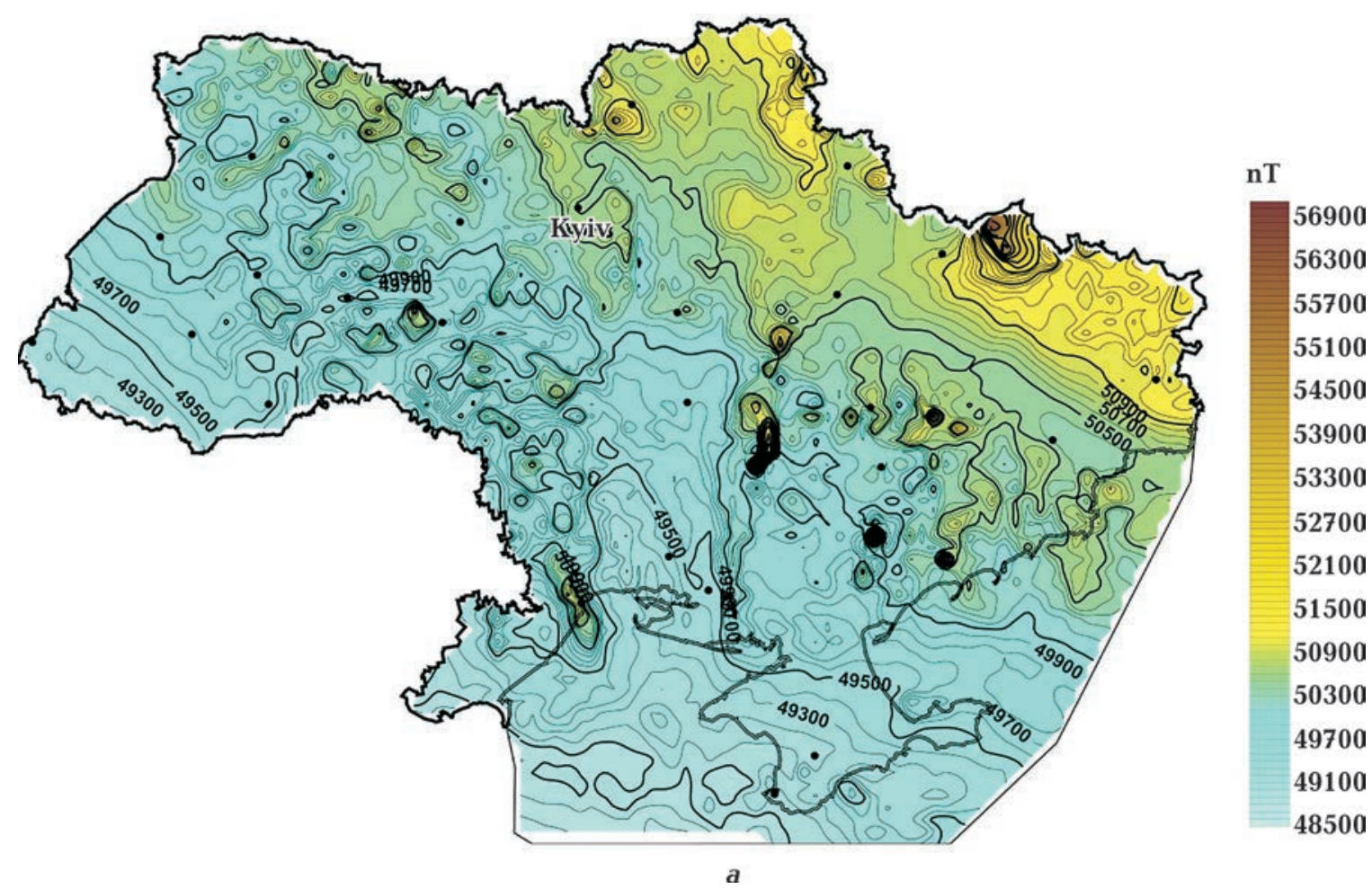

Fig. 4. Magnetic field induction module $B$ of the territory of Ukraine $(a)$, in the vicinity of the «AV» station (b) and Yamal (c) (epoch 2020). 


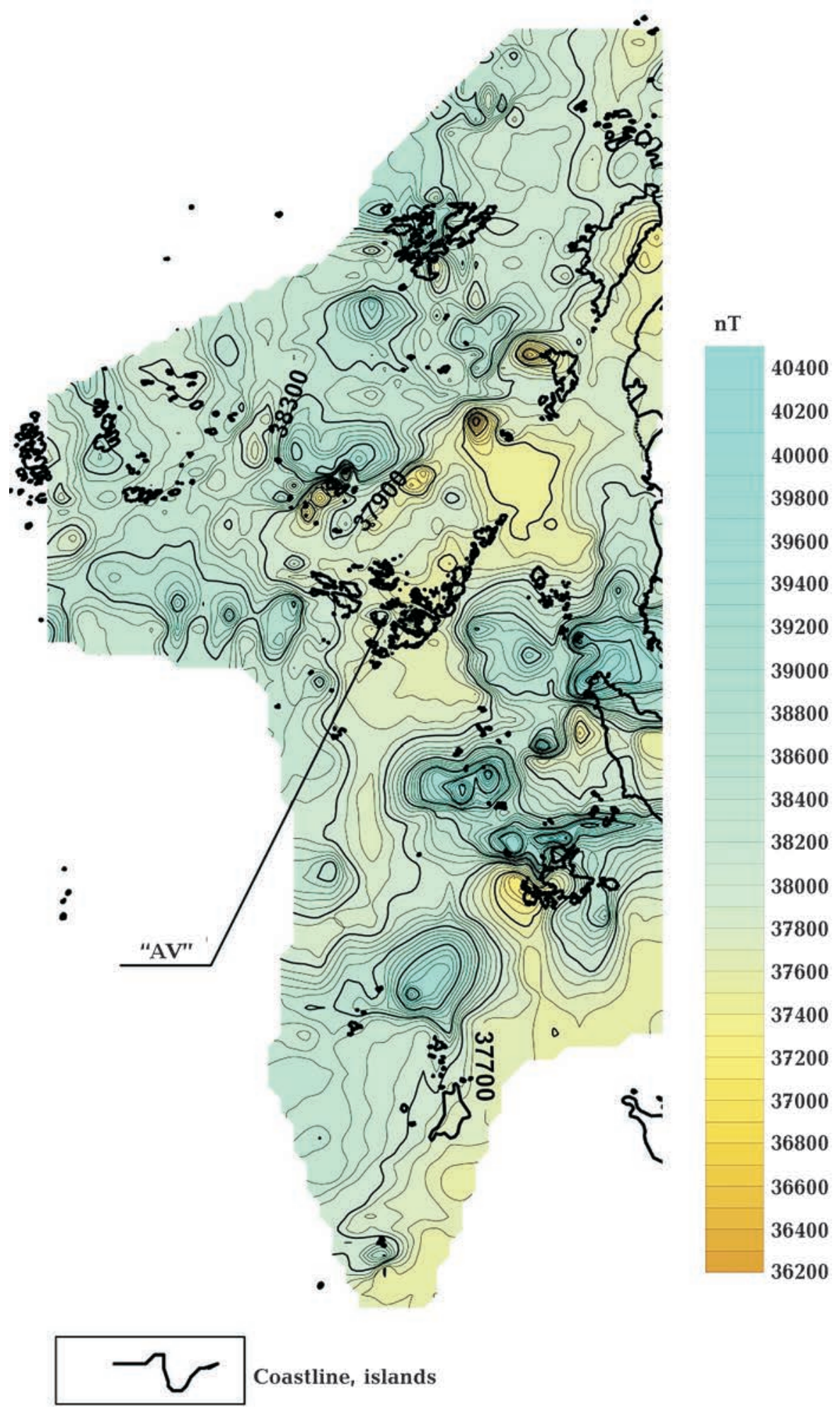

b

Fig. $4(b)$.

ed character of its magnetic field due to the complex structure of the Earth's crust of the Precambrian East European craton; Yamal
(Fig. 4, c) - in the nearpolar region close to the East Asian continental anomaly with a weakly differentiated field of the West Sibe- 

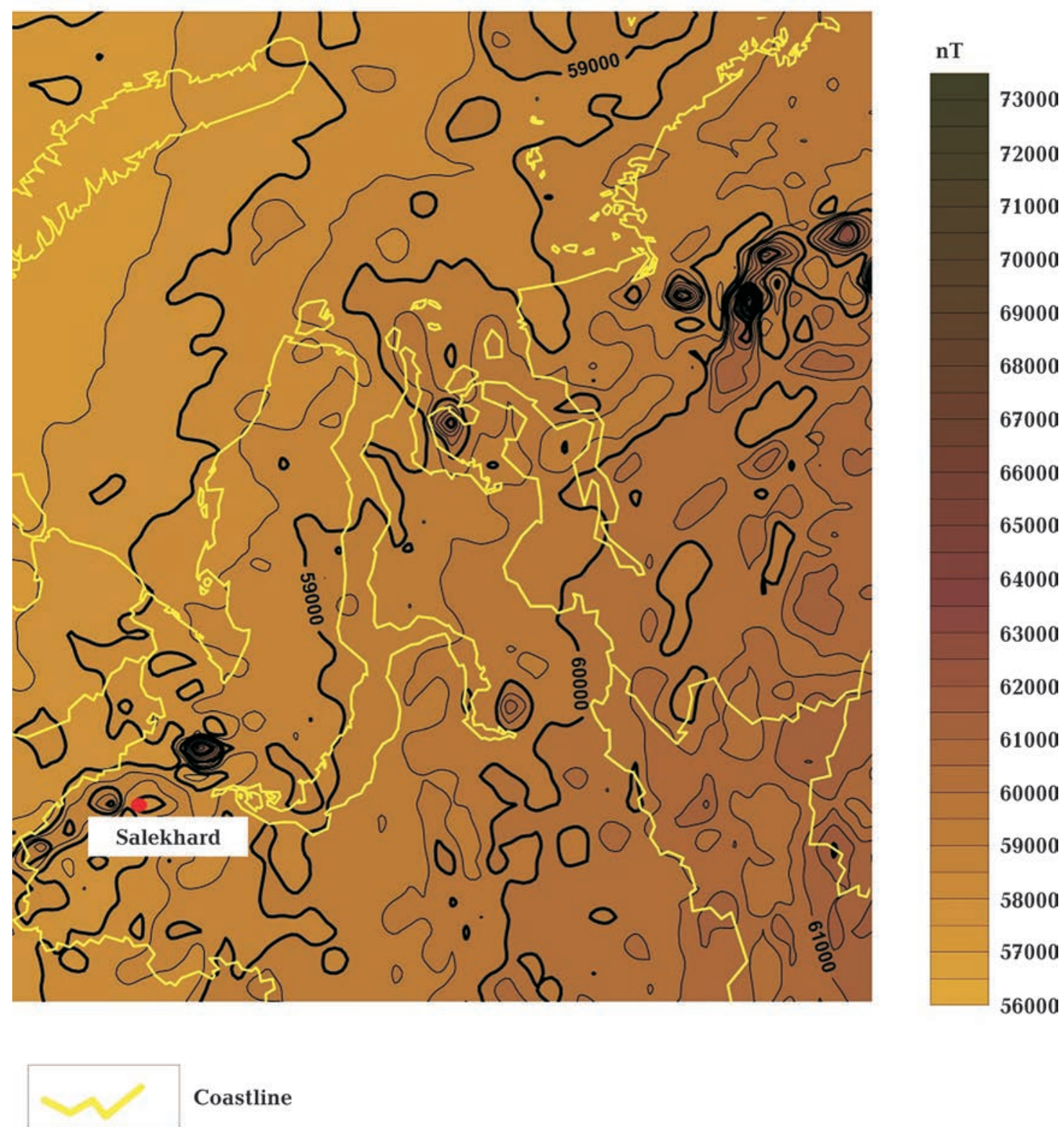

C

Fig. 4 (c).

rian plate of Mesozoic age. The territory of Antarctica (Fig. $4, b$ ) is generally poorly covered by magnetic measurements [Orlyuk, Romenets, 2009]. Studies conducted in the region of «AV» station indicate a significant heterogeneity of the geomagnetic field. Identified anomalies with an intensity of the first thousand nanoscale indicate the presence of rocks with very different magnetic properties. Therefore, an estimate of the spatial-temporal disturbance (heterogeneity) of the geomagnetic fields of these territories looks quite natural.
According to the obtained digital data, the full vector modulus of the geomagnetic field for Ukraine and Yamal varies within $B_{\mathrm{Ukr}, 1950}=$ $=46815 \div 54814 \mathrm{nT}, B_{\text {Yamal, } 1950}=54678 \div$ $\div 65579$ nT (epoch 1950) and $B_{\mathrm{Ukr}, 2020}=$ $=48707 \div 56806 \mathrm{nT}$ and $B_{\text {Yamal, } 2020}=56446 \div$ $\div 73449$ nT (epoch 2020), while the average values differ by more than $12000 \mathrm{nT}$. For the investigated territory near "AV» station, the full vector modulus varies within the limits of $B_{\text {«AV», } 1950}=41345 \div 48654 \mathrm{nT}$ (epoch 1950) and $B_{\text {«AV», 2020 }}=34221 \div 41530 \mathrm{nT}($ epoch 2020), that 


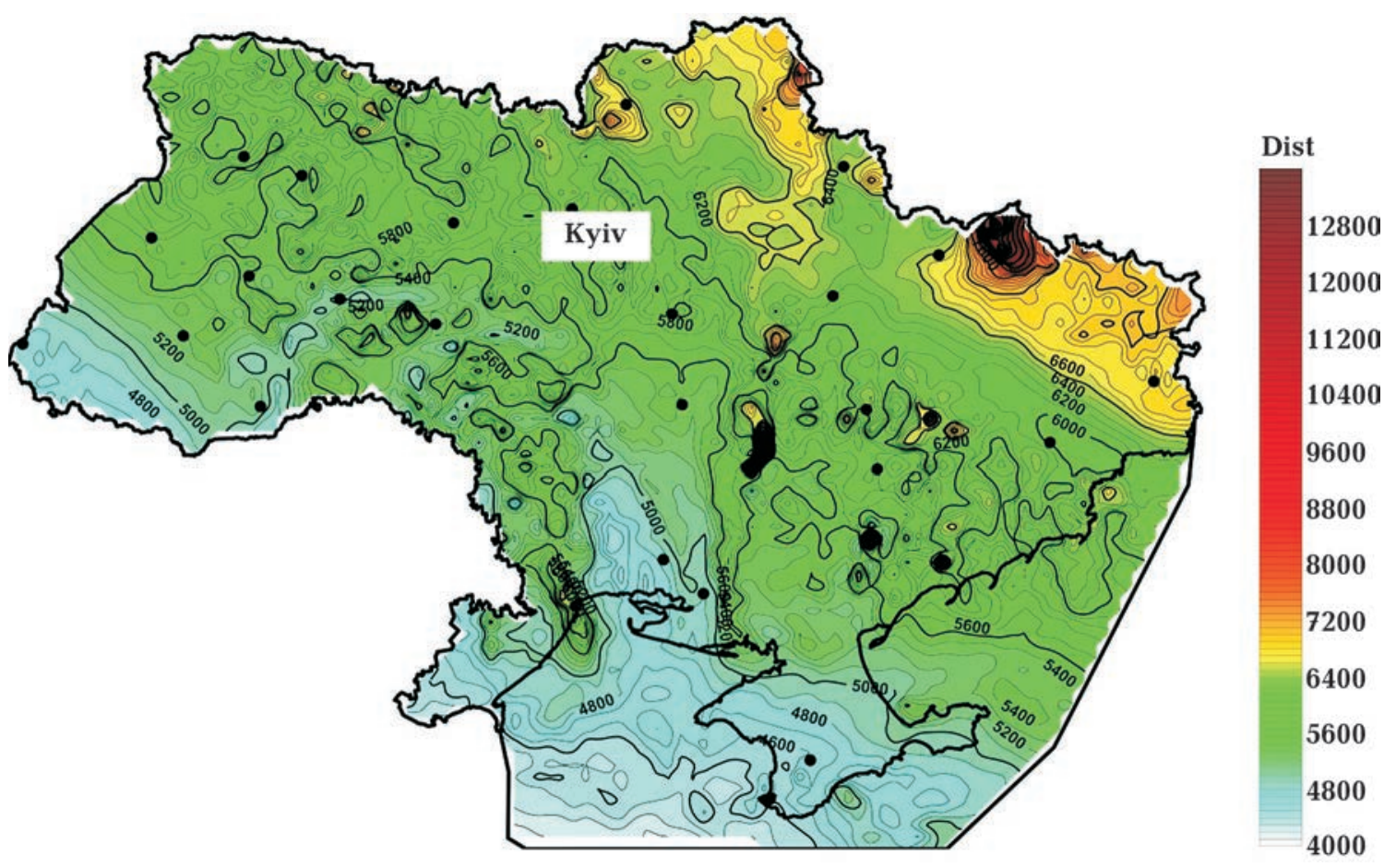

a

Fig. 5. Environmental perturbation of the geomagnetic field $D_{\text {ecol }}$ for the territory of Ukraine $(a)$, Yamal $(b)$, «AV» station $(c)$.

is on average, $15,000 \mathrm{nT}$ less than the average modulus of the full vector of the territory of Ukraine and 25,000 nT for Yamal.

As provided by the calculations, the ecological disturbance of the magnetic field on the territory of Ukraine varies between 4000 - $13200 D$, for Yamal — 13 000 - 25000D and for «AV» station - from -5200 to $-9800 D$. The time trend of the spatial disturbance of the magnetic field over 70 years has changed in the range from -409 to $+50 D$ (for Ukraine), from -563 to $+13 D$ (for Yamal) and from -777 to $+731 D$ (for «AV»). So, the dynamics of the perturbation of the magnetic field of Ukraine is significantly higher than that in Yamal, but significantly lower than the perturbation in the vicinity of " $\mathrm{AV}$ » station. The time trend of the environmental disturbance of the geomagnetic field over 70 years is within $\delta(\Delta D)_{\mathrm{ecol}}=1864 \div 2157 D$ (for Ukraine), $\delta(\Delta D)_{\text {ecol }}$ from -277 to $+5949 D$ (for Yamal) and $\delta(\Delta D)_{\text {ecol }}$ from -7914 to $-7916 D$ (for «AV») (Fig. 5).

Discussion of the results and conclusions. Fig. 6 shows a comparison of the isolines of the induction of the main magnetic field $B_{\text {IGRF }}$ for the epoch of 2020 and its secular variation over 70 years, from which a significant change in the geomagnetic field follows. In accordance with the above, the spatial-temporal characteristics of the geomagnetic field, indicating a very significant change for a short time interval, both for the whole planet and for its individual regions (see Fig. 6) should be considered as the main result of the study. The revealed decrease in the average value of the geomagnetic field induction $B$ (by almost $1800 \mathrm{nT}$ over 70 years) on its surface indicates a change in the shape of the magnetosphere and, accordingly, the heights of the upper and lower boundaries of the Van Allen radiation belt. Therefore, it is possible to indicate the weakening of the protective function of the Earth's magnetosphere and the deeper penetration of solar and cosmic matter into the Earth's atmosphere, as well as the approach to its surface of the heights of magnetospheric and ionospheric currents.

It should be also noted that in accordance with the accepted environmental norm of the 

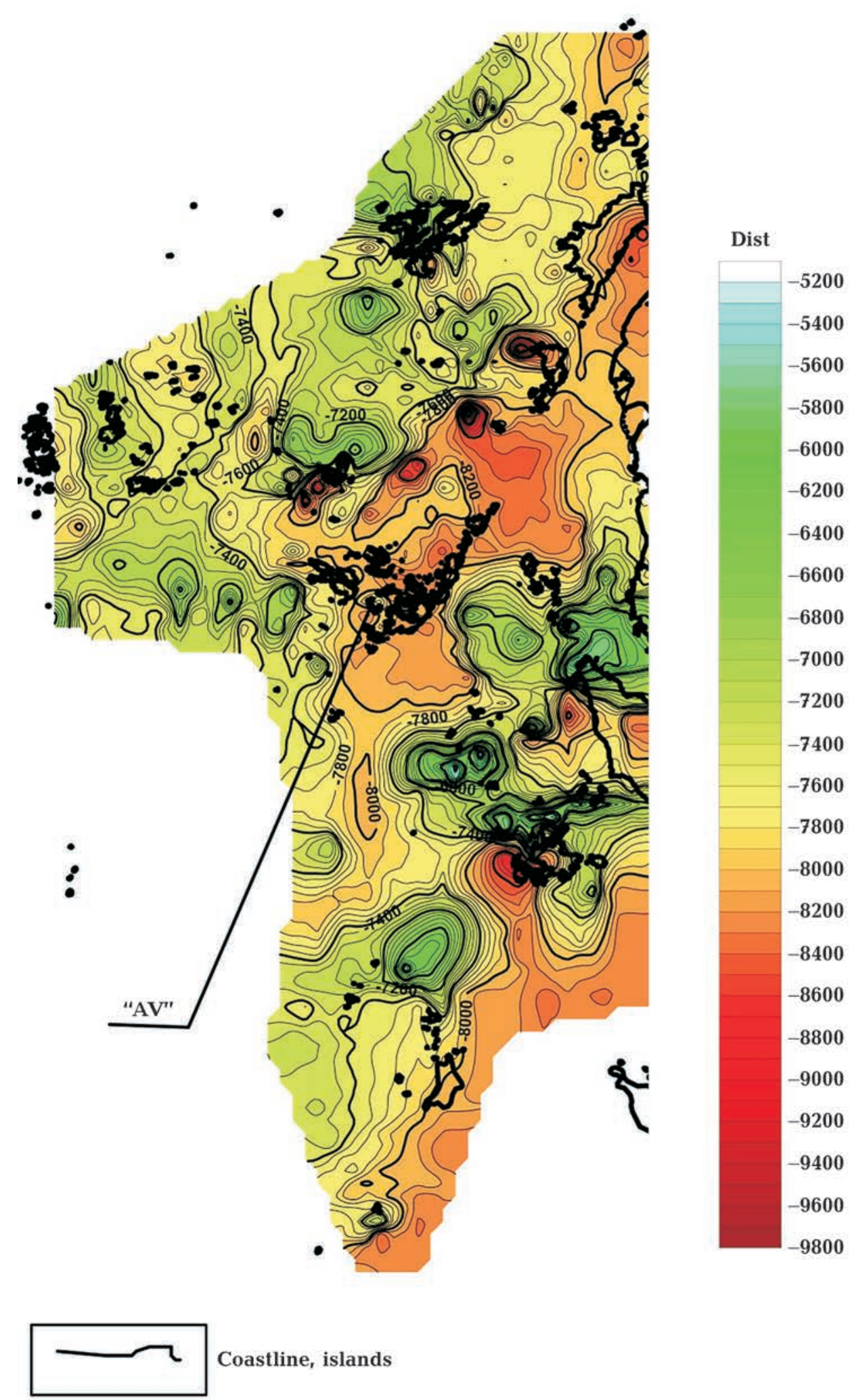

\section{b}

Fig. $5(b)$. 
magnetic field within $35000-55000 \mathrm{nT}$ (see Fig. 1, $a, b)$, territories with geomagnetically unfavorable living conditions can be distinguished on the Earth's surface. In particular, these are the territory of Canada, the Asian part of Russia, Central and South America, southwestern and southern parts of Africa and southern Australia. Due to the general decrease of the geomagnetic field, these areas slightly increase in size.
The second very important point is that against the background of a general decrease in the magnetic field of the planet, areas with its extreme change values are distinguished: maximums of field decrease are located near the Atlantic coast of Central America, in the Drake Strait, and also between Africa and Antarctica. Field maxima are typical for Europe and the Indian Ocean. This indicates an increase in the peculiar "contrast» of the

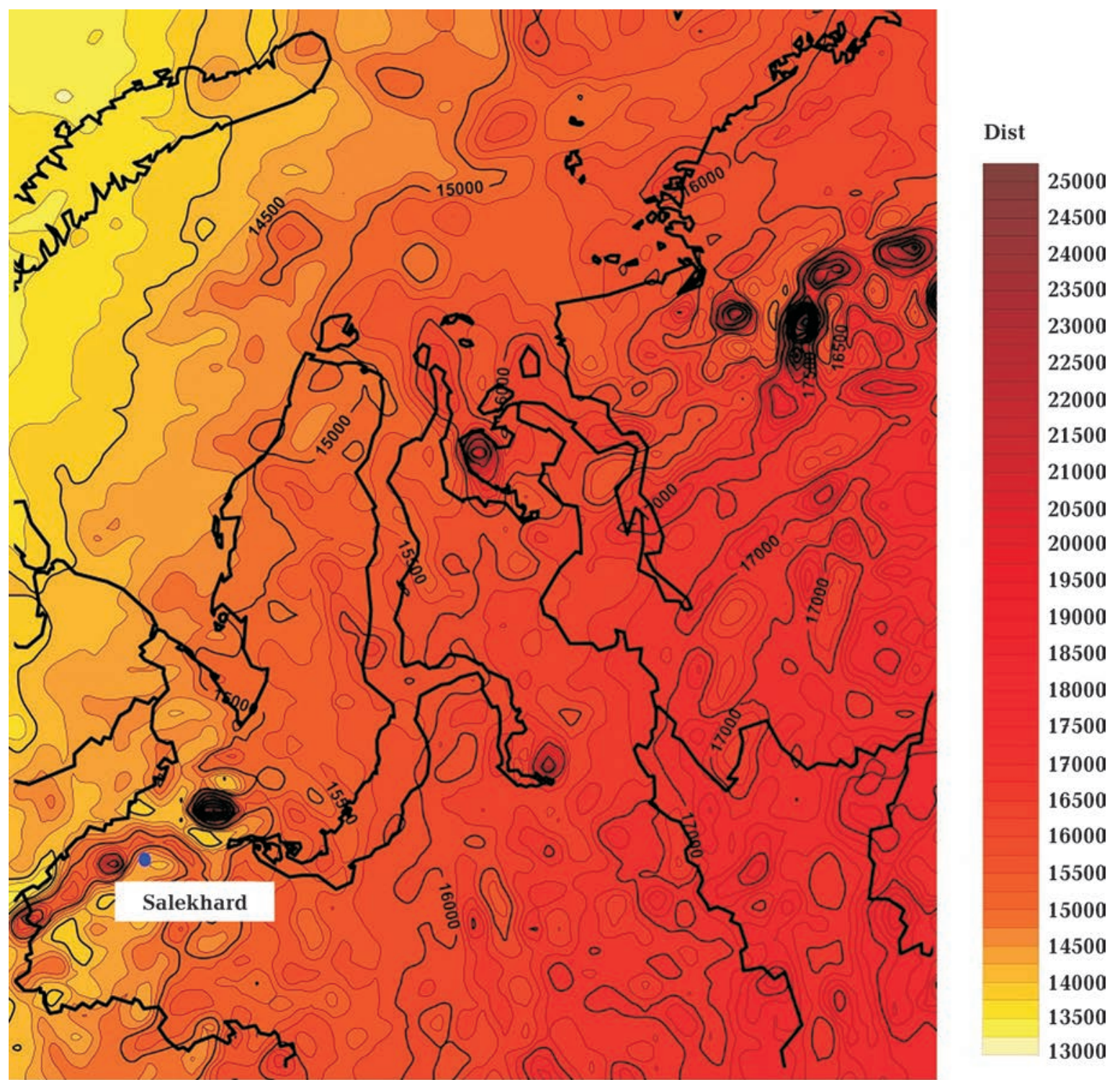

Coastline

C

Fig. 5 (c). 


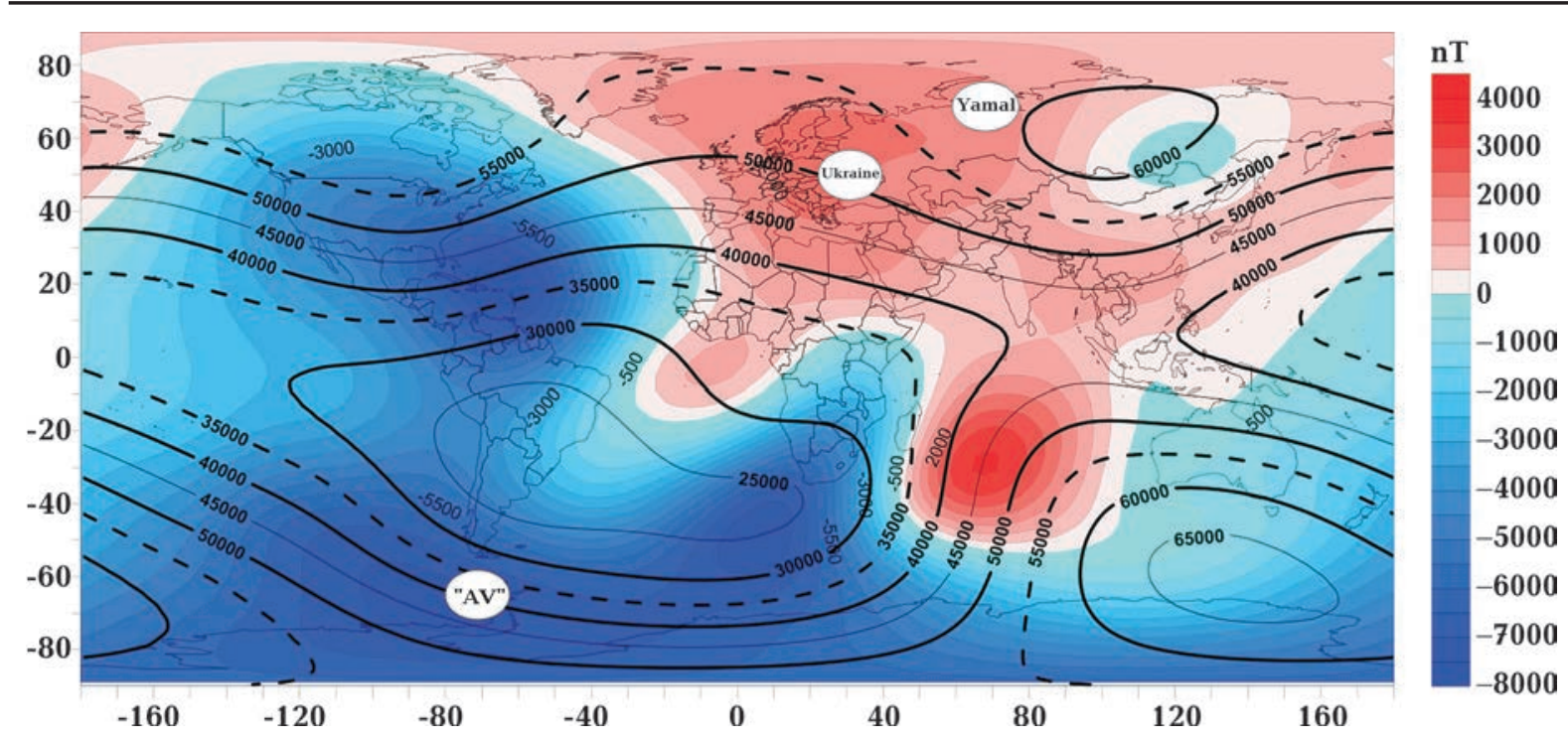

Fig. 6. Scheme for comparing the normal component of the $B_{\text {IGRF }}$ geomagnetic field for the epoch of 2005 and its temporal change for the time interval 1950-2020.

geomagnetic field and, accordingly, a complication of the magnetosphere configuration. In a number of works [Orlyuk, Romenets, 2011; Orlyuk et al., 2013a, b; Ryabov et al., 2019] it is shown that the heterogeneity of the geomagnetic field relief on the Earth's surface is manifested to one degree or another on the entire power of the magnetosphere and should affect the processes taking place in it. In [Orlyuk, Romenets, 2011], significant differences in the distribution of heights with the same values of the magnetic field induction for the planet as a whole are shown. We estimated the change in the geomagnetic field topography in the time interval 1950-2020 for the studied regions. According to calculations within $100-1000 \mathrm{~km}$ above the Earth's surface, heights with the same values of the induction of the geomagnetic field over 70 years increased by $80 \mathrm{~km}$ for the territory of Ukraine, by $55 \mathrm{~km}$ for Yamal and decreased by $380 \mathrm{~km}$ in the vicinity of «AV» station. Apparently, it is impossible that such significant changes do not affect a number of magnetospheric-ionospheric processes. A number of works [Cnossen et al., 2012; Olsen, Stolle, 2016 and others], in which it was shown that in the upper atmosphere at heights of 300 $800 \mathrm{~km}$ both the corresponding parameters of the internal geomagnetic field at these heights and short-term perturbations of the external magnetic field influence the spatial-temporal parameters of magnetospheric-ionospheric currents. In particular, it was shown that the internal geomagnetic field and its variations affect the change in the height of the region of maximum electron density in the ionosphere (from $-50 \mathrm{~km}$ in the region of the South Atlantic anomaly to 20 over West Africa, which, incidentally, is an order of magnitude higher than the decrease by $5 \mathrm{~km}$ of the corresponding height conditioned by an increase in $\mathrm{CO}^{2}$ concentration), and the maximum density of electrons in low-mid-latitude ionospheric current systems [Cnossen, 2014]. The correspondence of long-wavelength changes in the geomagnetic field with periods of 30, 55, and 180 days (identified by analysis of the perturbation of the geomagnetic field in the «Odessa» geomagnetic observatory [ Ryabov et al., 2019]) with variations of electrons and ions temperature in the upper ionosphere at the altitude of $500 \mathrm{~km}$ according to satellite observational data [Prabhakaran et al., 2004] is also shown.

In the environmental aspect, it is important that the considered regions with extreme values of geomagnetic field changes are either already regions with unfavorable geomagnetic conditions, or may become such ones in the 
near future if the identified trends in the field dynamics will continue. This is confirmed by the results given in the article on the estimate of the spatial-temporal disturbance of the geomagnetic field in Ukraine, Yamal and the «AV» station.

In particular, significant spatial changes in the geomagnetic field are shown, namely, for the epoch of 2020 for the territory near the «AV» station, the module of the induction vector $B_{\text {" } \mathrm{AV} \text { 》 }}$ is on average $15000 \mathrm{nT}$ less than its value in Ukraine and 25000 nT for Yamal. Significant temporary changes in the geomagnetic field were also determined: its growth by $1765 \mathrm{nT}$ for Ukraine, $1418 \mathrm{nT}$ for Yamal and a decrease by $7081 \mathrm{nT}$ in the vicinity of "AV» station.

Under accepted "environmental norm» of the perturbation of the geomagnetic field $( \pm 10000 D)$ in Yamal, its excess is observed (see Fig. $4, b)$, which makes this territory less «comfortable» compared to Ukraine (see Fig. 4, a), in the "geomagnetic sense», of course. The area near the "AV» station is characterized by intense temporary changes in spatial and environmental disturbances, which is explained by a decrease in the magnetic field reaching $-100 \mathrm{nT} /$ year in some years. The opposite picture is observed for the territories of Ukraine and Yamal, which are characterized by a regular increase in the geomagnetic field (see Fig. $4, c)$. Therefore, when the perturbation of the geomagnetic field deviates from the norm to its increase for Ukraine and Yamal, there is a significant decrease for «AV». It should be noted that in localities of intense positive anomalies in the area of «AV» station environmental disturbance is within normal limits.

In conclusion, it should be noted some correlation between the change of the geomagnetic field and temperature. The temperature changes in the regions of the planet that we are studying are taken from the databases [Index ..., 2020; KNMI ..., 2020]. In particular, the decrease of geomagnetic field induction over 70 years by $1800 \mathrm{nT}$, noted generally for the planet, is characterized by a regular increase in its average annual surface air temperature by $1.1^{\circ} \mathrm{C} / 100$ years for the period $1950-2019$. (Fig. 7, a). It should be noted that since the 70 s of the XX century temperature rose significantly.
Regions with extreme changes in the geomagnetic field are also characterized by corresponding increase in temperature. At «AV» station with a maximum magnitude of geomagnetic field decrease, the largest temperature increase from $-8{ }^{\circ} \mathrm{C}$ to $-2.5^{\circ} \mathrm{C}$ occurred in the interval 1957-1972, then it decreased to $-4.7^{\circ} \mathrm{C}$ in 1973 . From 1977 to 2010 , an increase in temperature from $-4.8^{\circ} \mathrm{C}$ to $-2.4{ }^{\circ} \mathrm{C}$ is observed, and then its relative decrease to $-3.0{ }^{\circ} \mathrm{C}$ follows (see Fig. $7, b$ ). Therefore, in the region of «AV» station, the average annual temperature for the studied time interval varied in the range of $-(8-2.4){ }^{\circ} \mathrm{C}$.

For Salekhard, the largest temperature change is confined to the interval 1970-2017, when the temperature increased from $-2.4^{\circ} \mathrm{C}$ to $0.1{ }^{\circ} \mathrm{C}$ (see Fig. $7, \mathrm{c}$ ). For Kyiv, during the studied time interval, the average annual temperature increased by more than $2.5^{\circ} \mathrm{C}$, and a significant increase began in 1985, and an even stronger increase was observed in the last 10 years (see Fig. $7, d$ ). In accordance with calculations, it can be noted that, as a first approximation, the temperature increases with changes in the geomagnetic field with high correlation coefficients for the planet as a whole $(r=-0.95)$, Salekhard $(r=0.81)$, Kyiv ( $r=$ $=0.81)$ and $" \mathrm{AV} »$ station $(r=-0.79)$ may indicate their relationship. A definite relationship is also taking shape between the annual growth of the geomagnetic field and the corresponding trends in temperature increase (see Fig. 3 and 7). But the revealed preliminary patterns require an in-depth analysis with a proposal for a mechanism for such an interconnection, etc., which was not part of the tasks of the work performed.

However, even without analyzing the causes and mechanisms of such an interconnection, we note the interdependence of these two important environmental factors, the direction of change of which is by no means aimed at improving the comfort of the environment for the organic world as a whole and for the human being in particular.

Acknowledgments. This study was carried out within the budget themes of the Institute of Geophysics S.I. Subbotin of the NAS of Ukraine: III-3-18 «Informativity of magne- 


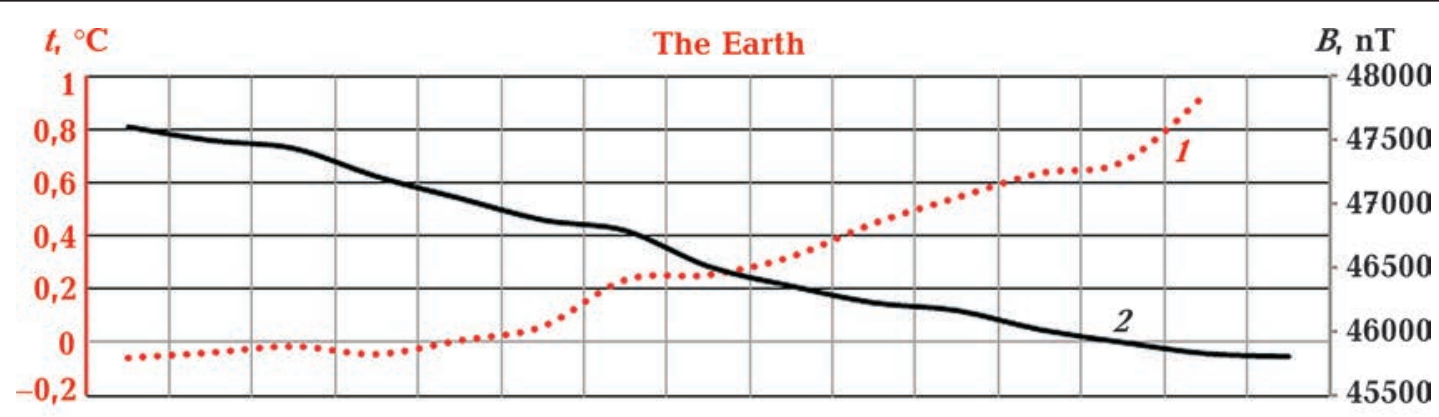

a

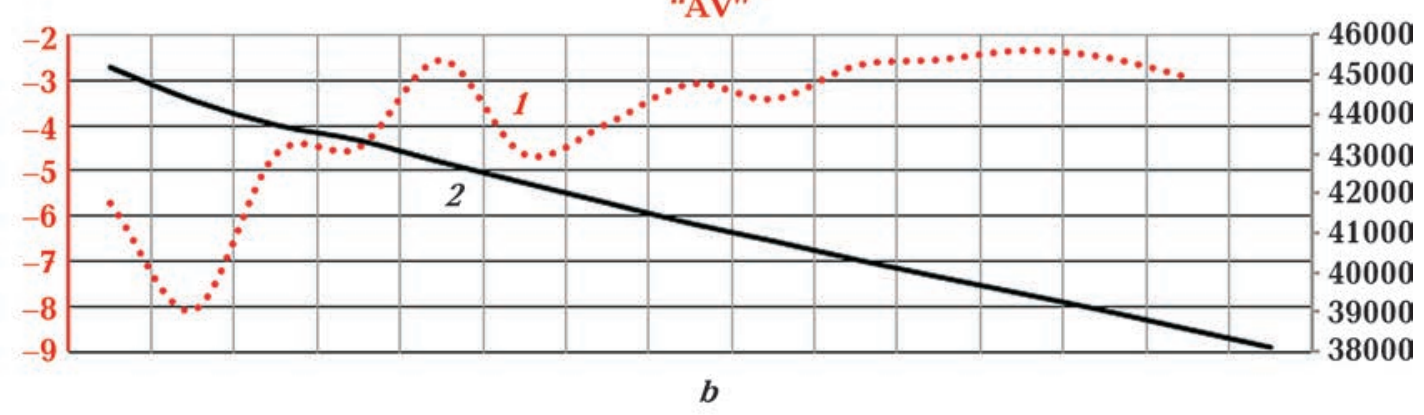

Salekhard

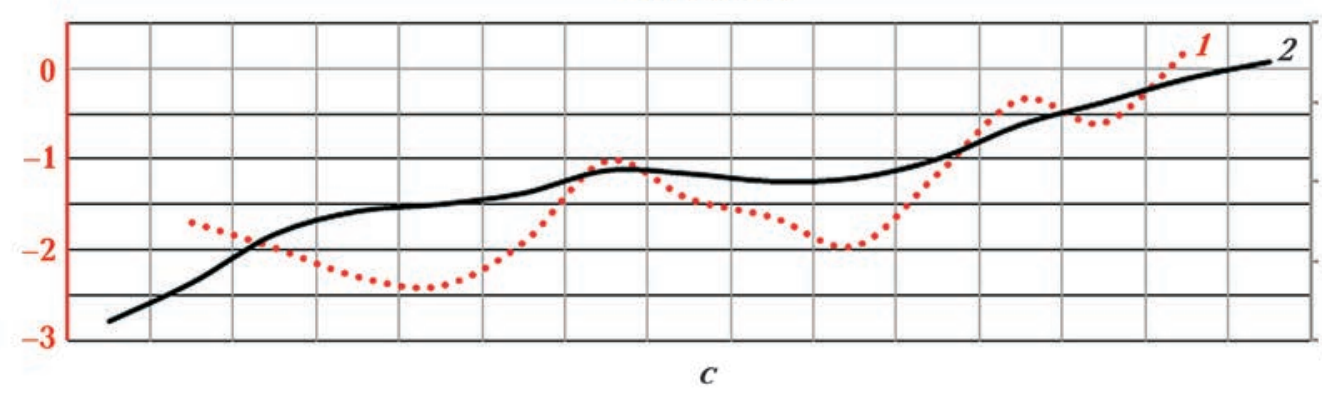

58500

58000 $-57500$ 57000 56500

Kyiv

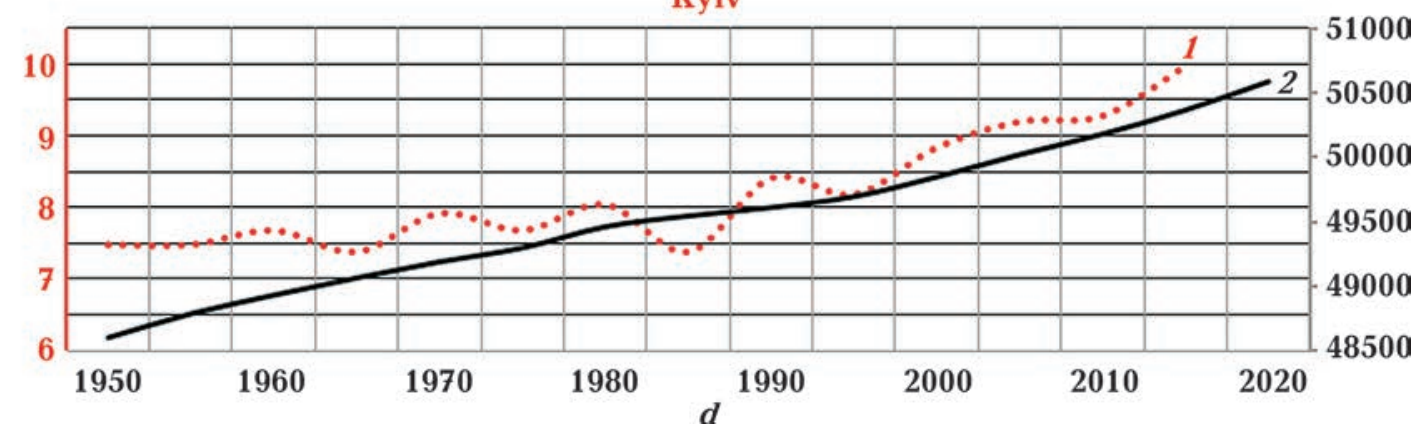

Fig. 7. Variation of the average annual temperature (with averaging over 5 years) for the planet $(a)$, "AV» station (b), Salekhard $(c)$ and Kyiv $(d)$ over the period from 1950 to 2019. Left scale is for temperature(1), right one is for geomagnetic field (2).

tic models of different ages tectonotypes of mantle-crustal structures to solve the problems of geodynamics and to forecast minerals in the territory of Ukraine» and III-23-17 "Monitoring of geophysical fields in order to reduce the risk of emergency situations from natural hazards». The authors are grateful to the staff of the Department of Geo- magnetism, Leading Scientific Researcher, Doctor of Geography S.G. Boychenko and junior researcher A.V. Marchenko, as well as Academician V.I. Starostenko and corresponding member V.E. Maksymchuk for participating in the discussion and comments made that have improved the article. Special thanks to Ye.Ye. Yeremenko for article translation. 


\section{References}

Belokrinitskiy, V.S. (2009). What users of mobile phones and computers need to know? Kiev: Ed. of «Ukraine» University, 112 p. (in Russian).

Cnossen, I. (2014). The importance of geomagnetic field changes versus rising $\mathrm{CO}^{2}$ levels for long-term change in the upper atmosphere. Journal of Space Weather and Space Climate, 4, A18.

Cnossen, I., Richmond, A.D., \& Wiltberger, M. (2012). The dependence of the coupled magnetosphere-ionosphere-thermosphere system on the Earth's magnetic dipole moment. Jour nal of Geophysical Research: Space Physics, 117, A05302. https://doi.org/10.1029/2012JA0 17555.

Dyment, J., Lesur, V., Hamoudi, M., Choi, Y., Thébault, E., \& Catalan, M. (2016). World Digital Magnetic Anomaly Map version 2.0. Abstract GP13B-1310 presented at the 2015 AGU Fall Meeting, San Francisco, Calif. Retrieved from http://www.wdmam.org.

Duma G., Leichter B., the MagNetE Group. (2013). Magnetic Declination Chart 2006 of Europe - produced by the MagNetE Group. Annals of Geophysics, 55(6), 1053-1059. doi: 10.4401/ag-5575.

Finlay, C.C., Olsen, N., Kotsiaros, S, Gillet, N., \& Toffner-Clausen, L. (2016). Recent geomagnetic secular variation from Swarm and ground observatories as estimated in the CHAOS-6 geomagnetic field model. Earth, Planets and Space, 68(112). https://doi.org/10.1186/s406 23-015-0232-0.

Frolov, A.F., Orlyuk, M.I., Zadorozhnaya, V.I., \& Romenets, A.A. (2009). Epidemic process of influenza and some factors of the biosphere of physical nature. Dopovidi NAN Ukrayiny, (1), 172-176 (in Russian).

Gorbunova, E.L. (2015). The influence of the intensity of the Earth's magnetic field on the reproductive function of sows. In Role of innovation in the transformation of modern science: collected articles of the International scientific and practical conference (pp. 25-27). Ufa: AETERNA (in Russian).

Havas, M., Shum, S. \& Dhalla, R. (2004). Passenoger exposure to magnetic field on go trains and on buses, streetcars, and subways run by the Toronto transit commission, Toronto, Canada. Biological Effects of EMFs, 3rd International Workshop, Kos, Greece 4-8 October, 2004 (pp. 1065-1071).

Henzl, C., Kacor, J., \& Palectr, J. (2006). Investigation of magnetic field in the subway station. Advances in Electrical and Electronic Engineering, 5(1-2), 254-257. https://crudata. uea.ac.uk/cru/data/temperature/HadCRUT4gl.dat

Index of /auto/Stations/TAVG/Text. (2020). Retrieved from http://berkeleyearth.lbl.gov/auto/ Stations/ TAVG/Text/.

KNMI Climate Explorer. (2020). Retrieved from http://climexp.knmi.nl/allstations.cgi? id= someone@ somewhere\& climate=temperature $\& n=12$.

Kulikov, V.Yu. \& Timofeeva, E.S. (2011). Evaluation of the combined effect of different variations of the geomagnetic and radiation fields on the osmotic resistance of human red blood cells in VITRO. Meditsina i obrazovaniye $v$ Sibiri, (4), 12-20 (in Russian).

Kurnikov, Yu.A., \& Orlyuk, M.I. (2011). Magneto-mineralogical characteristics, classification and use of natural magnetic sands. Geofizicheskiy zhurnal, 33(1), 39-53. https://doi. org/10.24028/gzh.0203-3100.v33i1.2011.117 323 (in Russian).

Kurnikov, Yu.A., \& Orlyuk, M.I. (2012). Fields of natural magnetic sands in systems for water treatment. Azov-Black Sea training ground for the study of geodynamics and fluid dynamics of the formation of oil and gas fields: Tenth international conference "Crimea-2012» (pp. 4243). Simferopol: Association of Geologists (in Russian).

Lowes, F.J. (2009). DC railways and the magnetic fields they produce - the geomagnetic context. Earth, Planets and Space, 61, I-XV. https://doi.org/10.1186/BF03352944.

Makarova, Z.A. (1977). Map of the anomalous magnetic field $(\Delta T)_{a}$ and the USSR (continental part and some adjacent water areas). 1 : 2500 000. Moscow: Ed. of the Main Directorate of Geodesy and Cartography, 16 p. (in Russian). 
Maksymchuk, V., \& Orlyuk, M. (2018). Magnetic field secular variations in Ukraine on the base of RS network observations. COBS Journal (Special Issue 5).

Maksymchuk, V.Yu., Orlyuk, M.I., \& Tregubenko, V.I. (2015). The basic geomagnetic network of Ukraine: state and development prospects. Actual problems and prospects of the development of geology: science and production. $\mathrm{Ma}$ terials of the International Geological Forum (September 7-12, 2015, Odessa, Ukraine)(Vol. 1, pp. 169-175). Kyiv: Publ. of the Ukrainian State Geological Exploration Institute (in Ukrainian).

Maksymchuk, V., Orlyuk, M., Tregybenko, V., Horodyskyy, Yu., \& Marchenko, D. (2012). Ukrainian geomagnetic repeat station on work and results of the field work reduced to the epoch 2005.5. Annals of Geophysics, 55(6), 1161-1165. doi: 10.4401/ag-5406.

Maksymchuk, V.Yu., Orlyuk, M.I., Tregubenko, V.I., Horodysky, Yu.M., Myasoedov, V.P., \& Nakalov, Ye.F. (2010). Terrestrial absolute magnetic field on the reference network of secular variation points in Ukraine for the epoch of 2005. Geofizicheskiy zhurnal, 32(6), 102-116 (in Ukrainian).

Maksymchuk, V.Yu., Orlyuk, M.I., Tregubenko, V.I., Marchenko, D.O., Nakalov, E.F., \& Chobotok, I.O. (2013). The results of component measurements of the magnetic field on a network of secular variation points 2005-2010. Geodynamika, (2), 219-222 (in Ukrainian).

Mandea, M., Korte, M. (Eds.). (2011). Geomagnetic Observations and Models. IAGA Special Sopron Book Series. Vol. 5. 343 p. doi: http:// doi.org/10.1007/978-90-481-9858-0.

Medvedeva, O.A., Kalutskiy, P.V., Besedin, A.V., Medvedeva, S.K., \& Kalutskiy, A.P. (2011). Ecological and epidemiological analysis of the incidence of intestinal infections in children in the areas of Kursk region with different levels of the geomagnetic field. Nauchnyye vedomosti. Ser. Meditsina. Farmatsiya, (10), 5-11 (in Russian).

Melnyk, P.P., Orlyuk, M.I., \& Romenets, A.A. (2014). Effect of magnetic field of Earth on the yield of winter wheat in the space-time dimension. Balanced Nature Using, 8(1), 85-93.
Melnyk, P.P., Orlyuk, M.I., \& Romenets, A.O. (2012). The influence of the Earth's magnetic field on winter wheat productivity in Ukraine. Naukovo-praktychnyy zhurnal zbalansovanoho pryrodokorystuvannya, (1), 53-60 (in Ukrainian).

Olsen, O., Ravat, D., Finlay, Ch.C., \& Kother, L.K. (2017). LCS-1: a high-resolution global model of the lithospheric magnetic field derived from CHAMP and Swarm satellite observations. Geophysical Journal International, 211(3), 1461-1477. https://doi.org/10.1093/gji/ggx 381.

Olsen, N., \& Stolle, C. (2016). Magnetic Signatures of Ionospheric and Magnetospheric Current Systems During Geomagnetic Quiet Conditions-An Overview. Space Science Reviews, 206, 5-25. https://doi.org/10.1007/ s11214-016-0279-7.

Orlyuk, M.I. (2007). Analysis of a geomagnetic field in Ecology. Retrieved from www.cosis. net/06649/EGS02-A-06649.pdf.

Orlyuk, M.I. (2001). Geophysical ecology: the main tasks and ways to solve them. Geofizicheskiy zhurnal, 23(1), 49-59 (in Ukrainian).

Orlyuk, M. (2013). Magnetic field of Ukraine: environmental (ecological) aspect. Proc. of the First Kyiv International Scientific Conference "Scientific and Methodological Foundations of Medical Geology» April 17, 2013. Kyiv, P. 18.

Orlyuk, M.I., Bakarjieva, M.I., Bakhmutov, V.G., Romenets, A.A., \& Tarasov, V.N. (2008). S4.4/ P13 Digital geomagnetic maps of Antarctic Peninsula. Polar Reserch-Arctic and Antarctic Perspective in the International Polar Year. Abstract Volume. Scientific Committee on antarctic Research (SCAR) and International Arctic Science Committee (IASC). Open science conference. St.Peterburrg, Russia, July $8^{\text {th }}-11^{\text {th }}$ (P. 423). St. Petersburg: Publ. of the State Research Center of the Russian Federation, the Arctic and Antarctic Research Institute.

Orlyuk, M.I., Frolov, A.F., Zadorozhnaya, V.I., \& Romenets, A.A. (2007). Perturbation of the Earth's magnetic field and some aspects of infectious diseases. Geofizicheskiy zhurnal, 29(6), 148-156 (in Russian).

Orlyuk, M.I., Marchenko, A.V., \& Bakarjie- 
va, M.I. (2013a). Kursk Magnetic Anomaly: analysis of anomalous magnetic field data based on ground, stratospheric and satellite surveys. Teoretychni ta prykladni aspekty heoinformatyky, (10), 107-116 (in Ukrainian).

Orlyuk, M.I., Marchenko, A.V., \& Ivashchenko, I.N. (2013b). Calculation of the full values of the components of the induction vector of the geomagnetic field B on the Earth's surface and satellite heights (by example of EEP). Problems of theory and practice of the geological interpretation of gravitational, magnetic and electric fields: Materials of the 40th session of the seminar named after D.G. Uspensky, Moscow, January 28-February 1, 2013) (pp. 251-254). Moscow: Ed. of the Institute of Earth Physics RAS (in Russian).

Orlyuk, M.I., Marchenko, A.V., \& Romenets, A.A. (2017). Spatio-temporal changes in the geomagnetic field and seismicity. Geofizicheskiy zhurnal, 39(6), 84-105. https://doi.org/10.24028/ gzh.0203-3100.v39i6.2017.116371 (in Russian).

Orlyuk, M., Marchenko, A., Romenets A., \& Bakarjieva M. (2018). Ukrainian Regional Magnetic Map: the results of calculations of the geomagnetic field components for the Epoch 2015. COBS Journal, (Special Issue 5), 40.

Orlyuk, M.I. Melnyk, P.P., Romenets, A.A., \& Lischetovich, L.I. (2012). On the effect of the Earth's magnetic field on the crop-producing power of winter wheat in the territory of Ukraine. Geofizicheskiy zhurnal, 34(2), 72-82. https://doi.org/10.24028/gzh.0203-3100.v34i2. 2012.116612 (in Russian).

Orliuk, T.M., \& Orlyuk, M.I. (2012). About a possible connection between leukemia diseases of cattle and the Earth's natural magnetic field. Naukovyy visnyk L'vivs 'koho natsional'noho universytetu im. S.Z. Hzhyts'koho, 14(2), 128132 (in Ukrainian).

Orlyuk, M.I., \& Romenets, A.A. (2008). Geomagnetic maps of the region of the station "Academic Vernadsky»: geological and ecological aspects. Ukraine in Antarctica - National Priorities and Global Integration/International Antarctic Conference IAC2008. May 23-25, 2008, Kyiv, Ukraine, International Polar Year 2007/8. Abstracts (P. 89).

Orlyuk, M.I., \& Romenets, A.A. (2003) Geomagnetic field of Ukraine: environmental aspect. Geolog Ukrainy, (1), 64-70 (in Russian).
Orlyuk, M.I., \& Romenets, A.O. (2017). Induction Module of the Earth's Magnetic Field and its spatiotemporal disturbance estimation for a number of territories of the northern and southern hemispheres. XI ${ }^{\text {th }}$ International Scientific Conference "Monitoring of Geological Processes and Ecological Condition of the Environment», 11-14 October 2017, Kyiv, Ukraine. Conference CD-ROM Proceedings. 5 p. (in Ukrainian).

Orlyuk, M.I., \& Romenets, A.O. (2004). Magnetic environmental field of a megalopolis (on the example of Kyiv). Ekolohiya i pryrodokorystuvannya, (7), 142-147 (in Ukrainian).

Orlyuk, M.I., \& Romenets, A.A. (2005). A new criterion for assessing the spatio-temporal disturbance of the Earth's magnetic field and some aspects of its use. Geofizicheskiy zhurnal, 27(6), 1012-1023 (in Russian).

Orlyuk, M.I., \& Romenets, A.A. (2009). Spatiotemporal structure of the geomagnetic field in the area of the Argentine Islands archipelago (AV station). Materials of the IX International Science Conference "Monitoring of geological processes» (Kiev, October 14-17, 2009) (pp. 92-94). HCV «Kiev University» (in Russian).

Orlyuk, M., \& Romenets, A. (2018a). Spatial-time disturbance of geomagnetic field for some territories of the north and southern hemispheres: ecological aspect. XVII ${ }^{\text {th }}$ International Conference on Geoinformatics - Theoretical and Applied Aspects. 14-16 May 2018, Kiev, Ukraine. Paper 13472_ENG. Conference CDROM Proceedings. 5 p.

Orlyuk, M.I., \& Romenets, A.O. (2018b). Spatiotemporal disturbance of the geomagnetic field of a number of territories of the northern and southern hemispheres of the Earth. Dopovidi NAN Ukrayiny, (10), 64-71. doi: https://doi. org/10.15407/dopovidi2018.10.064 (in Ukrainian).

Orlyuk, M.I., \& Romenets, A.A. (2011). The structure and dynamics of the Earth's main magnetic field on its surface and in near space. Odessa astronomical publications, 24, 124129 (in Russian).

Orlyuk, M., Romenets, A., \& Orliuk, I. (2016). Natural and technogenic components of megalopolis magnetic field. Geofizicheskiy zhurnal, 38(1), 78-86. https://doi.org/10.24028/ gzh.0203-3100.v38i1.2016.107727. 
Orlyuk, M.I., Romenets, A.A., Sumaruk, P.V., Sumaruk, Yu.P., \& Sumaruk, T.P. (2012). The spatio-temporal structure of the magnetic field of Ukraine's territory: assessment of the contribution of internal and external sources. Geofizicheskiy zhurnal, 34(3), 137-145. https://doi.org/10.24028/gzh.0203-3100. v34i3.2012.116651 (in Russian).

Orlyuk, M.I., Romenets, A.O., \& Sumaruk, T.P. (2005). Estimation and forecast of disturbances of the Earth's magnetic field. Teoretychni ta prykladni aspekty heoinformatyky, 246-260 (in Ukrainian).

Pavlovich, N.V., Pavlovich, S.A., \& Galliulin, Yu.I. (1991). Biomagnetic rhythms. Minsk: Universitetskoye, 136 p. (in Russian).

Physical factors of the work environment. Sanitary and epidemiological rules and regulations SanRuR 2.2.4.1191-03 «Electromagnetic fields and human health». (2003). Moscow, 19 p. (in Russian).

Prabhakaran Rannayar, S.R., Alexander, L.T., Radnick, V.N., John, T., Subrahmanyam, P., Chopra, P., Bahl, M., Maini, H.K., Singh, V., Singh, D., \& Garg, S.C. (2004). Observation of periodic fluctuations in electron and ion temperatures at the low-latitude upper ionosphere by SROSS-C2 satellite. Annales Geophysicae, 22(5), 1665-1674. doi: 10.5194/ angeo-221665-200.

Purucker, M.E. (2007). Magnetic Anomaly Map of the World. Eos, Transactions American Geophysical Union, 88(25), 263. https://doi.org/10. 1029/2007EO250003.

Purucker, M.E., \& Clark, D.A. (2011). Mapping and interpretation of the Lithospheric Magnetic Field. In: M. Mandea, M. Korte(Eds.), Geomagnetic Observations and Models (Vol. 5, pp. $311-337)$. IAGA Special Sopron Book Series. doi: 10.1007/978-90-481-9858-0.

Rezinkina, M.M., Pelevin, D.E., Dumanskiy, Yu.D., \& Bitkin, S.V. (2009). Weakening of the geomagnetic field in apartment buildings of various projects. Hihiyena naselenykh mists', (54), 209_216 (in Russian).

Rozov, V., Pelevin, D., \& Levina, S. (2013). An experimental study of the phenomenon of a static geomagnetic field reduction inside. Elektrotekhnika i elektromekhanika, (6), 72-76 (in Russian).
Romenets, A.A., \& Orliuk, I.M. (2013). Monitoring and analysis of low-frequency anthropogenic magnetic noise in the city of Kiev. Geodynamika, (2), 314-317 (in Russian).

Ryabov, M., Sukharev, A., Orlyuk, M., Sobitnyak, L., \& Romenets, A. (2019). Comparative analysis of geomagnetic disturbance in the zone of Odessa magnetic anomaly at different states of solar activity in the 24th cycle. Radiofizyka i radioastronomiya, 24(1), 68-79. https://doi.org/10.15407/rpra24.01.068 (in Russian)

Serdyuk, A.M., Grigoriev, P.Ye., Akimenko, V.Ya., \& Protas, S.V. (2010). Ecological significance of the geomagnetic field and biomedical prerequisites for hygienic regulation of its weakening in Ukraine. Dovkillya i zdorov'ya, (3), 8-11 (in Ukrainian).

Serpov, V. (2007). The influence of natural magnetic fields on human safety in the areas of geophysical anomalies in the European part of Russia: Extended abstract of Doctor $\$$ s thesis. St. Petersburg (in Russian).

Standard-2015 Randbedingungen: SBM-2015. (2015). Institut fur Baubiologie + Nachhaltin keit. 18 p. Retrieved from www.baubiologie.de.

Standart of Building Biology Testing methods: SBM-2008. (2008). Germany: Institut fur Baubiologie + Okologie. IBM. 12 p. Retrieved from https://buildingbiologyinstitute.org/wp-content/uploads/2019/03/SBM-2008C-v3.6.pdf.

Starostenko, V.I., Shuman, V.N., Pashkevich, I.K., Legostaeva, O.V., \& Savchenko, A.S. (2013). Methods for reconstructing harmonic functions from the magnetic field $\Delta T$ and V.N. Strakhov's function $\Delta S$ : review. Fizika Zemli, (1), 151-160. doi: 10.7868/S0002333713010158 (in Russian).

Thébault, E., Finlay, C. \& Toh, H. (2015). Special issue «International Geomagnetic Reference Field-the twelfth generation». Earth, Planets and Space, (67), 158. https://doi.org/10.1186/ s40623-015-0313-0.

Thébault, E., Purucker, M., Whaler, K.A., Langlais, B., \& Sabaka, T.J. (2010). The Magnetic Field of the Earth's Lithosphere. Space Science Reviews, 155(1-4), 95-127. https://doi.org/10. 1007/s11214-010-9667-6.

Travkin, M.P. (1971). Life in a magnetic field. 
Belgorod: Belgorod: Publ. of the Belgorod Pedagogical Institute, 192 p. (in Russian).

Tregubenko, V.I., Maksymchuk, V.Yu., Orlyuk, M.I., Myasoedov, V.P., Marchenko, D.O., \& Romenets, A.O. (2013). The components of the Earth's magnetic field in the territory of Ukraine for the epoch of 2010 according to the results of measurements in points of secular variations. Mineral'ni resursy Ukrayiny, (3), 37-40 (in Ukrainian).

Tyagunov, D.S. (2011). Anthropogenic electro- magnetic field as an environmental factor. Ekologiya urbanizirovannykh territoriy, (2), 45-50 (in Russian).

Witze, A. (2019). Earth's magnetic field is acting up and geologists don't know why. Nature, $565,143-144$.

Zasekin, D.A., Orliuk, T.M., \& Orlyuk, M.I. (2013). The study of the influence of geomagnetic field and magnetized water on technological indicators of chicken broilers. Veterynarna biotekhnolohiya, (22), 170-175 (in Ukrainian).

\title{
Просторово-часові зміни геомагнітного поля: екологічний аспект
}

\author{
М.I. Орлюк, А.О. Роменець, 2020 \\ Інститут геофізики ім. С.І. Субботіна НАН України, Київ, Україна
}

Геомагнітне поле нарівні з іншими факторами зовнішнього середовища є необхідною компонентою існування життя на Землі. В даний час існують відповідні екологічні норми величин постійних і змінних полів, з огляду на які визначають умови, необхідні для нормального функціонування біологічних об'єктів у цілому і людини зокрема. У ряді нормативних документів для постійного магнітного поля введені граничні величини, а також максимальний час можливого перебування людини в таких полях. У зв'язку з цим, у статті розглянуто просторово-часові зміни індукції $B$ на поверхні Землі для часового інтервалу 1950-2020 рр. на прикладі іiі головного магнітного поля за міжнародною моделлю IGRF-13. Більш детально для цього часового інтервалу проаналізовано модуль індукції $B$ і його збуреність для різних у геомагнітному відношенні регіонів, а саме території України, Ямалу (Росія) і довкола української антарктичної станції «Академік Вернадський». Аля планети в цілому показано істотне зменшення геомагнітного поля, з різкими скачками в 1960-1965 рр., 1980-1985 рр. та в 2000-2005 рр., але після 2005 р. по теперішній час спостерігається уповільнення швидкості його зменшення. На тлі зменшення геомагнітного поля планети виділяються зони з екстремальними його змінами як в сторону збільшення (Україна, Ямал), так і зменшення (станція «АВ»). Виявлені на поверхні Землі просторово-часові зміни геомагнітного поля визначають структуру та динаміку іiі магнітосфери, яка у свою чергу впливає на характер взаємодії з нею речовини сонячного вітру та космічного випромінювання, а також на висоти протікання низки процесів в іоносфері та атмосфері. Відповідно до розподілу аномалій геомагнітного поля на поверхні планети, а також їх змін за досліджений часовий інтервал виділено регіони з відмінними від запропонованих екологічних норм величинами постійного магнітного поля і його збуреності. Зокрема на епоху 2020 р. для

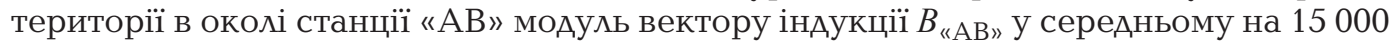
нТл меньше його величин для території України і на 25000 нТл - Ямалу. Визначено також суттєві зміни геомагнітного поля - збільшення на 1765 нТл для України, 1418 нТл - лля Ямалу і зменшення на - 7081 нТл в районі станції «АВ». За цього збуреність геомагнітного поля території України знаходиться в межах його «екологічної норми», на Ямалі відхиляється від неї в сторону збільшення, а поблизу станції «АВ» - скоро вийде за ії межі в сторону зменшення за збереження сучасних змін поля.

Ключові слова: геомагнітне поле, магнітосфера, просторово-часова збуреність, IGRF, екологічна норма, планета, Україна, Ямал, «Академік Вернадський». 


\title{
Пространственно-временные изменения геомагнитного поля: экологический аспект
}

\author{
М.И. Орлюк, А.А. Роменец, 2020
}

\author{
Институт геофизики им. С.И. Субботина НАН Украины, Киев, Украина
}

Геомагнитное поле наравне с другими факторами внешней среды является необходимым компонентом существования жизни на Земле. В настоящее время существуют соответствующие экологические нормы величин постоянных и переменных полей, учитывая которые, определяют условия, необходимые для нормального функционирования биологических объектов в целом и человека в частности. В ряде нормативных документов для постоянного магнитного поля введены предельные величины, а также максимальное время возможного пребывания человека в таких полях. В связи с этим, в статье рассмотрены пространственно-временные изменения индукции $B$ на поверхности Земли для временного интервала 1950-2020 гг. на примере ее главного магнитного поля по международной модели IGRF-13. Более подробно Аля этого временного интервала проанализированы модуль индукции и его возмущенность для различных в геомагнитном отношении регионов, а именно территории Украины, Ямала (Россия) и вокруг украинской антарктической станции «Академик Вернадский». Аля планеты в целом показано существенное уменьшение геомагнитного поля, с резкими скачками в 1960-1965 гг., 1980-1985 гг. и в 2000-2005 гг. Но после 2005 г. до настоящего времени наблюдается замедление скорости его уменьшения. На фоне уменьшения геомагнитного поля планеты выделяются области с экстремальными его изменениями как в сторону увеличения (Украина, Ямал), так и уменьшения (станция «Академик Вернадский»). Обнаруженные на поверхности Земли пространственно-временные изменения геомагнитного поля определяют структуру и динамику ее магнитосферы, которая, в свою очередь, влияет на характер взаимодействия с ней вещества солнечного ветра и космического излучения, а также на высоты протекания ряда процессов в ионосфере и атмосфере. Согласно распределению аномалий геомагнитного поля на поверхности планеты, а также их изменениям за исследованный временной интервал выделены регионы с отличающимися от предложенных экологических норм величинами постоянного магнитного поля и его возмущений. В частности, на эпоху 2020 модуль вектора индукции $B$ для территории в окрестности станции «Академик Вернадский» в среднем на 15000 нТА меньше, чем для территории Украины, и на 25000 нТл, чем для Ямала. Определены существенные изменения геомагнитного поля - увеличение на 1765 нТл для Украины, 1418 нТл для Ямала и уменьшение на 7081 нТл в районе станции «Академик Вернадский». Поэтому возмущенность геомагнитного поля территории Украины находится в пределах его «экологической нормы», на Ямале отклоняется от нее в сторону увеличения, а вблизи станции «Академик Вернадский» скоро выйдет за ее пределы в сторону уменьшения при сохранении современных изменений поля.

Ключевые слова: геомагнитное поле, магнитосфера, пространственно-временная возмущенность, IGRF, экологическая норма, планета, Украина, Ямал, «Академик Вернадский». 